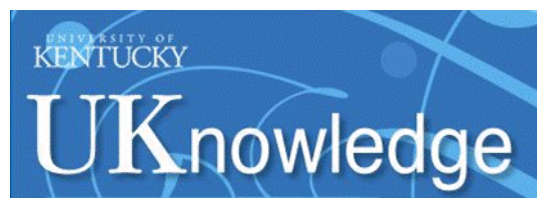

University of Kentucky

UKnowledge

\title{
Survey of Czechoslovak Laws Affecting East-West Trade
}

Stephen J. Vasek Jr.

University of Kentucky College of Law, vaseks@uky.edu

Follow this and additional works at: https://uknowledge.uky.edu/law_facpub

Part of the Comparative and Foreign Law Commons, and the International Trade Law Commons

Right click to open a feedback form in a new tab to let us know how this document benefits you.

\section{Recommended Citation}

Stephen J. Vasek, Survey of Czechoslovak Laws Affecting East-West Trade, 20 Am. J. Comp. L. 453 (1972).

This Article is brought to you for free and open access by the Law Faculty Publications at UKnowledge. It has been accepted for inclusion in Law Faculty Scholarly Articles by an authorized administrator of UKnowledge. For more information, please contact UKnowledge@lsv.uky.edu. 


\section{Survey of Czechoslovak Laws Affecting East-West Trade}

Notes/Citation Information

American Journal of Comparative Law, Vol. 20, No. 3 (Summer 1972), pp. 453-484 


\section{Survey of Czechoslovak Laws Affecting East-West Trade}

Between 1960 and 1967 all of the major codes of Czechoslovak laws were redrafted. The culminating work in the redrafting process was the New Economic Model (NEM) which became effective in January, 1967.1 Under the NEM, allocation of resources and trade decisions were to be made primarily on the basis of profitability. ${ }^{2}$ The key to the implementation of the profit motive was the new market price system, under which prices were eventually to be determined by supply and demand rather than set by administrative fiat. Bonuses were to be paid workers and managers based upon the profitability of their enterprise. After the 1968 Warsaw Pact Occupation of Czechoslovakia the NEM was abandoned, although the law was not repealed. ${ }^{3}$ The most recent Czechoslovak Five-Year Plan evidences the return to centralized planning by directive: it condemns the establishment of a market price system, fixes detailed goals for each industry and favors the integration of the Czechoslovak economy into COMECON. ${ }^{4}$ Although the NEM has been abandoned, the Warsaw Pact occupation has not caused the repeal of any of the other codes enacted in Czechoslovakia during its "liberal" period.

\section{Code RELATIONShips}

\section{A. Regulation of the Substantive Law of Obligations}

In Czechoslovakia three codes contain the substantive law of obligations: the Civil Code, the Economic Code and the International Trade Code (hereafter "ITC"). ${ }^{5}$ This division of the substan-

StEPHEN J. VASEK is Assistant Professor of Law, University of Kentucky.

1. New Economic Model, Principles of the Improved System of Planned Direction of the National Economy, approved by the Czechoslovak Communist Party Central Committee 30 Jan. 1965. Sbírka Zákonu 90/1965.

2. See generally Michal, "Czechoslovakia's Foreign Trade," 27 Slavic Rev. 212 (1968); Holesovsky, "Planning Reforms in Czechoslovakia," 19 Soviet Studies 544 (1968); Toman, "Uvod do zásad nové soustávv planevítého rízeni" (Introduction to the Basic Principles of the New System of Management Planning), 1 Za vyssí úroven planovíteho rizeni (Management Planning on the Higher Level) 35 (1965). Sik, "Czechoslovakia's New Economic Management System," 9 New Times 8 (1965).

3. See J. Zielinski, "Economics and Politics of Economic Reforms in Eastern Europe," 9 Economics of Planning 279 (1969); "World Strength of Communist Party Organizations," U.S. Dept. of State, Bureau of Intelligence and Research, 23rd Annual Report 66-67 (Pub. no. 8526, 1971).

4. "Directives for the Fifth Five-Year Plan for the Development of the Czechoslovak Economy between 1971-1975," 9/10 Czechoslovak Foreign Trade, Special Suppl. at 15 (1971).

5. Civil Code, Act no. 40/1964; Economic Code, act no. 109/1964; International Trade Code (hereafter "ITC"), Act no. 101/1963. 
tive laws of ogligations into three separate codes was made to facilitate the use of different laws to protect different interests in what were thought to be basically different economic situations. The basic economic situations are the sale for consumption, the domestic commercial sale and the international commercial sale. The legal systems of civil law countries and to some extent the Uniform Commercial Code recognize the different interests involved in consumer sales and commercial sales. The division of commercial sales into domestic and foreign sales is unique even for a socialist country in that other socialist countries apply their Civil Code to regulate foreign trade transactions. ${ }^{6}$ It is necessary to understand this three-way division of Czechoslovak contract law to ascertain which law governs, e.g., a particular sale of goods or contract of carriage.

\section{B. The Civil Code}

The Civil Code governs relations (including relations based on tort, protection of personality, and inheritance) between citizens and socialist organizations and between two or more citizens "arising in the course of the satisfaction of their material and cultural needs." E.g. it governs the purchase of a coat by a Czechoslovak citizen for his use from another Czechoslovak individual or a Czechoslovak retail store. The Civil Code establishes the following hierarchical ordering of interests protected: first, the interests of society, ${ }^{8}$ next the interests of individuals, ${ }^{9}$ and, finally the interests of socialist commercial organizations. ${ }^{10}$

6. E.g. the Principles of Civil Legislation of the U.S.S.R. and the R.S.F.S.R. Civil Code 1964 are the laws controlling foreign trade transactions in the Russian Socialist Federated Soviet Republic. Giffen, The Legal And Practical Aspects of Trade with the Soviet Union 121 (1969).

7. Civil Code, s. 1. As in other civil law countries, family and labor relations are governed by special laws and not by the Civil Code.

8. E.g. Civil Code art. V provides, "Civil-law relations give rise ... also to rights and obligations with respect to society." Civil Code art. VII states, "No person may abuse his rights against the interests of society or his fellow citizens, nor may he enrich himself to the detriment of society or his fellow citizen." Civil Code s. 125 provides, "Property acquired from an illicit source shall not enjoy the protection extended to personal ownership", and s. 130(2) states that "Things accumulated in contradiction with the interests of society in excess of the personal needs of the owner, his family and household shall not enjoy the protection extended to personal ownership."

9. The Civil Code puts greater burdens on socialist commercial organizations than on individuals; e.g. s. 225 states, "Organizations providing services shall be obliged to create conditions for their provision so as to satisfy properly and steadily the socially warranted demands of individuals," and s. 247-55 establish a six months' guarantee of quality and quantity of goods sold to individuals.

Transactions between individuals are generally regulated in part $\mathrm{V}$ of the Civil Code on the basis of equality of the parties; e.g. the seller (individual) is only liable for defects in goods of which he had knowledge. S. 400. See Kalensky \& Kopac, "The New Czechoslovak Code of International Trade," 5 Bull. Czech. L. 145, 152 (1964) (hereafter "Kalensky \& Kopac").

10. Generally, the socialist economic organization is only entitled to re- 
Since communist theory proclaims the unity of the interests of society and its individual members, it is arguably theoretically incorrect to rank the interests of society above the interests of the individual. From a practical viewpoint, however, the Civil Code protects the interests of society when individual interests conflict with the interests of society; e.g. property obtained through speculation escheats to the state. The emphasis on the protection of individuals in their dealings with socialist organizations is necessitated by the great power with which such organizations are frequently entrusted, a situation similar to that in the U.S. which is prompting the promulgation of deceptive practice acts and consumer credit codes.

\section{The Economic Code}

The Economic Code regulates the organization and status of socialist organizations as well as their mutual economic relations. ${ }^{11}$ The reason for not regulating economic relations between socialist organizations in the Civil Code or the ITC is that socialist organizations, although enjoying legal personality "are, in fact, administrators of property owned by society and must therefore act in a manner which will suit and benefit society." 12 This theory of the function of socialist organizations conflicted with the profit motivation scheme contained in the original New Economic Model which sub silencio presumed the equivalency of profit motivated self-interest and societal interests. The post-occupation NEM, which provides for greater planning by directive and greater reliance upon state determined economic parameters, does not rely primarily on profit motivated self-interest to promote societal interests and therefore appears to be consistent with the Economic Code's command that the State actively direct the development of the economy. The Economic Code provides for the establishment, change or abolition of binding

ceive payment for goods or services furnished individuals according to the prescribed rates. See generally discussion of the Economic Code, infra.

11. Economic Code, s. 1. The term "socialist organization" includes "State, cooperative and public organizations, as well as other organizations whose activities contribute to the development of socialist relations." Economic Code, s. 14. State organizations are usually either economic or budgetary organizations (s. 27), the former having independent legal personality (s. 47) and the latter operating within the State Budget (s. 60(2)). State economic organizations are roughly comparable to capitalist trades or businesses, whereas state budgetary organizations are like capitalist public health or public culture agencies. Cooperative organizations, e.g. unified agricultural cooperatives, land improvement cooperatives, producer cooperatives, consumer cooperatives, housing cooperatives, are legal persons and membership in them is voluntary (s. 76). Public organizations are voluntary organizations of individuals active primarily in the political, cultural and social spheres (s. 97), but may establish subsidiary enterprises or economic facilities which have legal personality (s. 102).

12. Vins, "The Legal Provisions Governing Economic Obligations," 6 Bull. Czech. L. 22, 24 (1965). 
obligations between parties without their consent, by government "planning acts", ${ }^{13}$ by order of a superior agency ${ }^{14}$ or by order of an economic arbitration court. ${ }^{15}$ These methods of establishing, changing or abolishing contractual rights were to be used only exceptionally under the original NEM, ${ }^{10}$ but can be expected to be used frequently under the post-occupation NEM. It is primarily due to these governmental powers to establish, alter or abolish contractual rights in order to further societal interests that the Economic Code is unsuited for regulating transactions with foreign firms.

The economic relations between state foreign trade firms and domestic socialist organizations, arising out of deliveries for export or from imports, are also regulated by the Economic Code. ${ }^{17}$ Since the Economic Code does not apply to relations regulated by the ITC, ${ }^{18}$ the Economic Code does not regulate all the economic relations of state foreign trade firms. Moreover, with respect to state foreign trade firms, the Economic Code does not regulate " $[t]$ heir establishment, capacity to acquire rights and undertake obligations, management, organization and other property and legal status ...."19 These enumerated aspects of the regulation of state foreign trade firms are regulated by Law 119/1948 $5 \mathrm{~b} .{ }^{20}$

\section{The International Trade Code}

The ITC regulates property relations arising in international commercial transactions where Czechoslovak law has been chosen by the contracting parties or is applicable on the basis of private international law (choice of law). Laps and gaps in the coverage of specific situations by the ITC are filled by application of the principles underlying the ITC, ${ }^{21}$ e.g. the principles of full equality under the law and the inadmissibility of discrimination between

13. Economic Code s. 161-64, 270.

14. Ibid. s. 118.

15. Ibid.

16. "These provisions are necessary for those cases where, for one reason or another, even those needs of customers would not be satisfied, in whose satisfaction society has a special interest and which therefore may be defined as "public orders" ". Vins, supra n. 12 at 26.

The use of planning acts under the NEM was to be limited primarily to securing deliveries and sub-deliveries for:

"(a) tasks explicitly set by the Government,

(b) planning tasks of scientific and technological development,

(c) securing the defensive capacity of the State,

(d) export and vital needs of health care."

Economic Code, s. 115(2).

17. Economic Code, s. 389 (1). See also Special Provisions Relating to deliveries for Export and from Imports, Economic Code, s. 211-58.

18. Ibid. s. $389(2)$.

19. Ibid. s. $389(1)$.

20. Bystricky, Právo Mezinárodního Obchodu (The Law of International Trade) 22 (1967).

21. ITC, s. 723. 
the parties. ${ }^{22}$ The provisions of the Economic Code and the Civil Code are not to be applied, even in an auxiliary sense, to transactions falling within the ambit of the ITC. ${ }^{23}$ The Czechoslovak approach to the problem of laps and gaps can be contrasted with the West German approach. Under German law gaps in the Commercial Code are filled by reference to the Civil Code, e.g. to determine remedies for a breach of contract. For a socialist state, the Czechoslovak approach to filling laps and gaps is preferable to the German approach because of the inappropriateness of governing relations with foreign trading partners by domestic laws applicable to a situation where there is state-ownership of the means of production. ${ }^{24}$

The applicability of the ITC is based on the nature of the transaction (objective basis) and is not necessarily based on the character of the parties, i.e. whether they are Czechoslovaks or foreigners, socialist organizations or capitalist enterprises. ${ }^{25}$ In order to be regulated by the ITC a transaction must have both commercial and international character.

1. Commercial character means that the contract was not "knowingly" entered into for the purpose of satisfying the personal or other needs of one of the parties on Czechoslovak territory. ${ }^{26}$ If the relations do not have this commercial character, they are regulated by the Civil Code. $^{27}$ The purpose of the commercial character requirement is to protect foreigners from discrimination (they are treated like nationals while in Czechoslovakia) and to protect the integrity of the socialist system. The requirement is applicable regardless whether the party whose needs are satisfied in Czechoslovakia is an individual or a legal person. ${ }^{28}$

A common example of transactions not having the requisite commercial character usually involves tourists who "buy various articles, stay in hotels or eat in restaurants" in Czechoslovakia. ${ }^{29}$ Bystricky also cites the case of a representative of a foreign airline who "buys various necessities, rents rooms, etc." 30 Nevertheless, the ambiguity with regard to the scope of application of the ITC has caused considerable controversy among Czechoslovak scholars. ${ }^{31}$ of course, the state monopoly of foreign trade limits the possibilities of

22. ITC, s. 1.

23. ITC, s. 3; See Kalensky \& Kopac, supra n. 9 at 154-55.

24. See discussion of Economic Code and Civil Code in text, supra.

25. Bystricky, supra n. 20 at 23 . Cf. Kalensky \& Kopac, supra n. 9 at 153 , 158.

26. ITC, s. 2(2); Bystricky, supra n. 20 at 26.

27. Kalensky \& Kopac, supra n. 9 at 157.

28. Ibid. at 158; Bystricky, supra n. 20 at 26-27.

29. Kalensky \& Kopac, supra n. 9 at 157; Bystricky, supra n. 20 at 26-27.

30. Bystricky, ibid. at 27.

31. Rohlik, "Zakoník mezinárodního obchodu v soudní praxi (The Law of International Trade in Judicial Practice)," Socialisticka Zakonnost (Socialist Lawyer) 3 (1967). 
sales by foreigners directly to Czechoslovak consumers, and state ownership of the means of production limits the possible commercial activities of foreigners in Czechoslovakia. Yet even in the past, socialist organizations other than foreign trade firms were occasionally allowed to transact foreign trade and, under the New Economic Model, some foreign trade firms may be merged into the producing socialist organization. ${ }^{32}$ Presumably sales of equipment or supplies directly to a production enterprise which purchases those goods to satisfy its needs in Czechoslovakia would have the requisite commercial character to be governed by the ITC. Also, foreign companies occasionally maintain offices in Czechoslovakia and frequently participate in trade fairs in Czechoslovakia. Obligations incurred in maintaining these offices and exhibits presumably will be governed by the provisions of the ITC. The use of foreign exchange by a foreigner to purchase goods in Czechoslovakia, if linked with an intent to export the purchased goods for resale or if linked with an intent to use the goods in Czechoslovakia or abroad in connection with some commercial enterprise, should make the provisions of the ITC applicable to the purchase transactions. ${ }^{33}$ Further refinements in the definition of commercial character must await case law development.

2. International character: The international character of property relations governed by the ITC is necessarily broadly defined due to the wide variety of activities regulated by that Act. But the ITC is not applicable to transactions of the requisite international character, if those transactions do not also have the requisite commercial character.

The following property relations have international character under the ITC: ${ }^{34}$

1. Relations between parties who do not have their seat (domicile) in the same country:

(a) the transfer of any title, right or interest for a valuable consideration (ITC s. 2(1) (a)), e.g. sale of goods, transfer of patent, copyright or trademark rights.

(b) contractual relations (ITC s. 2(1) (c)), e.g. contracts of work (ITC s. 475-90), commission contracts (ITC s. 50520), commercial representatives' contracts (ITC s. 40509), exclusive purchase contracts (ITC s. 410-14).

32. "[F]oreign trade is carried out by special foreign trade organizations ... exceptionally-foreign trade is carried out even by other enterprises. ... Such specific exceptions are often made by the granting of import and export licenses ... . whereas, in general, state trading firms need not secure such licenses." Knapp, "The Function, Organization and Activities of Foreign Trade Corporations in the European Socialist Countries," in Schmitthoff, The Sources of the Law of International Trade (1964).

33. See generally Rohlik, supra n. 31 .

34. See generally Bystricky, supra n. 20 at 28-30. 
(c) relations between a bank and its client (ITC s. 2(1) (f)), e.g. letters of credit (ITC s. 653-60), collection through banks (ITC s. 661-64), banking guarantees (ITC s. 66575), travellers' checks (ITC s. 676-80).

(d) other property relations between merchants (ITC s. $2(1)$ (i)).

2. Property relations involving activities in a country where none of the parties has his seat (domicile):

(a) property relations involving the use of a thing, right or economic interest in such contry (ITC s. 2(1) (b)), e.g. a lease (ITC s. 439-53) or bailment (ITC s. 431-38) of property in such country, or the right to use patents, trademarks, etc. in such country.

(b) Certain transportation relations discussed infra, 3 (c).

3. Property relations arising in the course of transport:

(a) property relations arising in the course of providing for, or effecting carriage of goods by sea, or chartering vessels by demise, or concluding other charter parties (ITC s. $2(1)(d))$.

(b) property relations arising in the course of transport other than by sea, where the place of shipment and the place of destination are not in the same country (ITC s. 2(1) (e)).

(c) property relations arising in the course of transport other than by sea, where the place of shipment and the place of destination are in the same country but none of the parties has his seat (domicile) in such country (ITC s. $2(1)(e))$.

4. Other property relations arising in connection with one of the preceding property relations (ITC s. 2(1)(i)), e.g. bankerclient relations (ITC s. 2(1)(f)), insurance against risk of loss or damage (ITC s. 2(1)(g)), inspection activities (ITC s. 2(1) (h)) .

The property relations described in 2-4 above are regulated by the ITC even if the parties to the transaction are all from the same country and even if that country is Czechoslovakia. Furthermore, the relations described in 1 above are regulated by the ITC even when the goods do not leave the state in which the offer and acceptance were made. This arrangement should be contrasted with the Hague Uniform Law for the International Sale of Goods (1964) ${ }^{35}$ (hereafter "Hague Uniform Sales Law") which "applies only to transactions that have a double international aspect-with respect 
to both the parties and the sales transaction."36 The purpose of the double test of international character in the Hague Uniform Sales Law is to prevent its application to transactions between two parties operating in the same country or to transactions where the goods did not leave the state in which the offer and acceptance were made. ${ }^{37}$ The difference in the scope of application of the ITC and the Hague Uniform Sales Law is understandable when the following factors are considered: (1) the broader scope of activities regulated by the ITC (most of the activities described in 2-4 above are not regulated by the Hague Uniform Sales Law), and (2) the inappropriateness of regulating activities of foreigners by the Czechoslovak Economic Code since that Code is not based on the concept of freedom of contract.

\section{E. The General Conditions}

In addition to the Civil Code, the Economic Code and the ITC, there is also a fourth source of substantive law regulating contractual obligations of Czechoslovak nationals. This fourth source, in some respects more important to Czechoslovak foreign trade firms than the other three, is the General Conditions for the Delivery of Goods between member states of the Council for Mutual Economic Assistance (Comecon). ${ }^{38}$ Since trade relations between Czechoslovakia and most of its socialist trading partners are governed by the General Conditions and are only governed by the ITC in an auxiliary manner, ${ }^{39}$ the ITC could discriminate against Western foreign trading partners without discriminating against socialist-bloc trading partners.

The General Conditions do in fact establish different rules for Comecon trade than are established by the ITC for trade with the West. E.g. the General Conditions provide for the recovery of penalties in addition to damages for breach of contract; ${ }^{40}$ the ITC only provides for the recovery of damages. The General Conditions provide that all disputes arising out of the contractual relationship are to be decided only in special arbitration tribunals; ${ }^{41}$ courts of gen-

36. Honnold, "The Uniform Law for the International Sale of Goods: The Hague Convention of 1964," 30 Law \& Contemp. Prob. 326, 332 (1965).

37. Tunc, Commentary on the Two Hague Conventions of 1964, in Records of the Conference, supra n. 35 at 361 .

38. An English translation of the 1958 Comecon General Conditions can be found in Berman, "Unification of Contract Clauses in Trade Between Member-Countries of the Council for Mutual Economic Aid," 7 Int'l \& Comp. L.Q. 659 (1958). An English translation of the 1968 Comecon General Conditions can be found in Hoya \& Quigley, "Comecon 1968 Conditions for the Delivery of Goods," 31 Ohio St. L.J. 1 (1970).

39. ITC, s. 4.

40. See generally Katona, "The International Sale of Goods Among Member States of the Council for Mutual Economic Assistance," 9 Colum. J. Transnat'l L. 226, 270-76 (1970).

41. 1968 General Conditions of Delivery, s. 90. See Grzybowski, "The 
eral jurisdiction are not precluded from deciding disputes arising in East-West trade. These rules for Comecon and East-West trade do not present a case of adverse discrimination against East-West trade for two reasons: First, the state monopoly over foreign trade and the close relationship between the state and its foreign trade firms in Comecon countries make it reasonable to expect the Comecon state to assert control over specific contractual provisions such as damage remedies and arrangements for dispute settlement. A Western state generally would not be expected to legislate regarding matters traditionally left to the discretion of enterprises located within its territory, such as liquidated damages clauses or arbitration clauses. Secondly, even if the special treatment given Comecon trade were not justified on the basis of the special relationship between Comecon member states and their foreign trade firms, it could be justified on the basis of the special relationship among Comecon member states. Because of the integration of Comecon member states' economies and the reciprocal application of the General Conditions, it is reasonable that socialist bloc trading partners receive special treatment, in much the same manner that EEC members are entitled to special benefits of EEC membership. ${ }^{42}$ Therefore, a detailed analysis of the General Conditions would not be especially useful in evaluating the "fairness" of the ITC for Western trading partners. Fairness of the ITC is evaluated infra by comparison of the ITC with the commercial laws of Western countries and multilateral commercial treaties designed to regulate trade among capitalist states.

\section{F. Regulation of International Trade in General}

Besides the ITC, the most important pieces of legislation in Czechoslovakia regulating international trade are the Act concerning Private International Law and the Rules of Procedure Relating Thereto $^{43}$ (hereafter the "Private International Law Act"), and the Act Relating to Arbitration in International Trade and to Enforcement of Awards"4 (hereafter the "International Arbitration Act"). The Private International Law Act governs choice of law problems and international procedural law, the latter category including questions of jurisdiction, procedure, and the recognition and execution of foreign judgments. The International Arbitration Act governs, inter alia, the arbitrability of issues, choice of law governing the va-

Foreign Trade Regime in the Comecon Countries Today," 4 N.Y.U. J. Int'l L. \& Politics 183, 205 (1971).

42. It has also been argued that special legal regulation is justified for Comecon trade since that trade is not profit motivated, but based upon the interests of individual members and Comecon as a whole. See Katona, supra n. 40 at $232-33$.

43. Act no. $97 / 1963$.

44. Act no. $98 / 1963$. 
lidity of arbitration agreements, and enforcement of arbitration awards.

The relationship between the three acts is based on s. 3 of the ITC which provides that the ITC will be applied when Czechoslovak law is the governing law as determined by the provisions of private international law (which are included in the Private International Law Act and the International Arbitration Act). Conversely, the International Arbitration Act applies to "property claims arising out of international trade . ..,"45 and this term will probably be interpreted to mean primarily claims based on "property relations arising out of international trade" ${ }^{\prime 4}$ as defined in the ITC. ${ }^{47}$

\section{JURISDICTION}

A. Subject Matter Jurisdiction

S. 7 of the Code of Civil Procedure provides:

(1) In civil proceedings, courts consider and decide matters arising from relations governed by civil, labor, family and cooperative law unless such matters are reserved under the law for the consideration and decisions of other agencies.

(2) Courts consider and decide other matters in civil proceedings only if the law so provides.

In civil proceedings the courts consider property relations regulated by the Civil Code and the ITC. ${ }^{48}$ Economic-legal relations between Czechoslovak socialist-economic organizations, which are regulated by the Economic Code, are not included in the general subject matter jurisdiction of the courts. Disputes between socialist organizations are settled primarily by economic arbitration before specified arbitration agencies and only in a limited number of situations, described in Act no. 121/1962, are those disputes settled by the courts. ${ }^{49}$

\section{B. Jurisdiction over the Parties}

S. 37(1) of the Private International Law Act provides that "Czechoslovak courts shall have jurisdiction in property disputes (i.e. primarily disputes invoving rights based on the law of obliga-

45. Ibid. s. 2.

46. ITC, s. 1 .

47. Cf. Zourek, "New Rules of Arbitration Proceedings in Czechoslovakia," 4 Bull. Czech L. 235 (1964). The subject matter jurisdiction of the Czech Arbitration Commission may perhaps include some claims ex delictu or quasi ex delictu which are not regulated by the ITC.

48. Ceska, "The New Czechoslovak Rules of Civil Procedure," 6 Bull. Czech L. 149, 156 (1965).

49. Ibid.; Stajgr, "Procesní podminky a jejích zjistováni (Procedural Conditions and their Ascertainment)," Acta Universitatis Carolinea-Iuridica 3, 9 (1966). 
tions) if they are competent to act under Czechoslovak law." This provision embodies the principle that a Czechoslovak court has jurisdiction if it has local competence (venue.) ${ }^{50}$ Whether the venue provision sets "precise limits" on the jurisdiction of Czechoslovak courts in property disputes appears to be a debatable issue, although the Czechoslovak writers appear to support the proposition that a Czechoslovak court would not assume jurisdiction if it lacked local competence. ${ }^{51}$

The Code of Civil Procedure provides that a particular Czechoslovak court has venue if the defendant has his residence (individuals) or seat (juristic persons) within the district of that court.52 If the defendant has no permanent residence, then the court within whose district he is staying has venue. ${ }^{53}$ Jurisdiction based on where the defendant is staying is different from the common law physical presence basis of jurisdiction because the former is applicable only if the defendant has no permanent residence and presumably requires more of a connection between the state and the defendant than the defendant's driving through the state or flying over it. Since Western trading firms are unlikely to have their seat in Czechoslovakia (and individual entrepreneurs are unlikely to have a permanent residence in Czechoslovakia), these basic jurisdictional rules of Czechoslovak law will rarely be applicable in obtaining jurisdiction over foreign trading parties.

The following venue provisions are more important to foreign trading parties. They give venue to the Czechoslovak court within whose district:

1) the defendant has property, ${ }^{54}$ or

50. Singer, Právo $v$ Zahranicním Obchodu (The Law of Foreign Trade), 545 (1968); Heyer, "K problemátice právomoci a prislusnosti Cs. soudu ve vztázich $\mathbf{k}$ cizinè (Problems of Jurisdiction and Competence of Czechoslovak Courts over Relations with Foreigners)," 10 Cásopis pro Mezinárodni Právo (Journal of International Law) 226, 232 (1966).

51. Prior to the enactment of the Private Internatnal Law Act, jurisdiction in property disputes was determined on the basis of local competence. Bystricky, Základy Mezinárodního Práva Soukromého (Fundamentals of Private International Law) 125 (1958); The Private International Law Act supposedly did not change the existing law regarding jurisdiction of Czechoslovak courts. Bystricky, "The New Czechoslovak Act concerning Private International Law and The Rules of Procedure Relating Thereto," 4 Bull. Czech. L. 209, 228 (1963).

However, s. 11(3) of the 1963 Code of Civil Procedure provides:

If the case involved is within the jurisdiction of the Czechoslovak courts but the conditions of local competence are lacking or cannot be determined, the Supreme Court shall decide which court will consider and decide the case.

It has been stated that s. 11(3) will only be applied to "cases which undoubtedly belong under the jurisdiction of the Czechoslovak courts. . .." Ceska, supra n. 48 at 157 .

52. Code Civ. Proc., s. 85.

53. Ibid. s. $85(1)$.

54. Ibid. s. $86(2)$. 
2) a foreign organization has representation or an agency authorized to handle its economic affairs, ${ }^{55}$ or

3) "the fact establishing the right to compensation of damages took place," $" 50$ or

4) "the place of payment is located in cases involving assertion of rights arising from a bill of exchange or a check,"

5) the seat of the arbitration board, which dealt with the transaction, is located, ${ }^{58}$ or

6) "the Czechoslovak socialist organization asserting rights established in the course of the performance of its tasks has its seat. ..."59

Jurisdiction can be based on the presence in Czechoslovakia of defendant's property ${ }^{60}$ regardless whether the property is tangible or intangible, ${ }^{61}$ movable or immovable. ${ }^{62}$ Such jurisdiction is not limited by the value of the property, nor is it limited to claims which bear some relationship to the property. ${ }^{63}$ Jurisdiction based on property is only available if no other court in Czechoslovakia has jurisdiction, and can only be used to decide property rights, i.e. generally rights based on the law of obligations. On the basis of this jurisdiction a Czechoslovak court could grant a $\$ 100,000$ judgment against a foreign defendant who had a $\$ 10$ claim against a Czechoslovak organization, even if that Czechoslovak organization was the one seeking the $\$ 100,000$ judgment. $^{.4}$

Although presence of assets as a basis for in personam jurisdiction has been criticized as being "exorbitant" Austria, Japan, the Swiss Cantons and Sweden also have provided for in personam jurisdiction based on the presence of defendant's

55. Ibid. s. 86(3). The specific delegated powers encompassed by the phrase "authorized to handle its economic affairs" are not stated in the Code.

56. Ibid. s. 87 (b).

57. Ibid. s. 87 (e). The purpose of this provision is to facilitate the presentation of claims for payment of bills of exchange and checks, Cf. Bystricky, Základy Mezinárodního Práva Soukromého, supra n. 51 at 457.

58. Code Civ. Proc., s. 88 (g).

59. Ibid. s. 87 (d).

60. See text accompanying $n .54$ supra.

61. E.g. it could be a claim against a Czechoslovak subject in Czechoslovakia. Singer, supra n. 50 at 554.

62. The Czechoslovak court in whose district lies immoveable property has exclusive venue (except in divorce cases) to decide the rights in such property. Code Civ. Proc., s. 88(h). This exclusive jurisdiction does, not, however, limit the jurisdction of the court in deciding only questions relating to the rights in the property.

63. Singer, supra n. 61 at 546.

64. Ibid.

65. Steiner and Vagts, Transnational Legal Problems 665 (1968); Nadelmann, "Jurisdictionally Improper Fora," in Nadelmann, Von Mehren and Hazard, XXth Century Comparative and Conflicts Law 321 (1961). These foreign laws appear less extraordinary when placed alongside the New York long-arm Statute which claims personal jurisdiction over non-domiciliaries who "own use or possess real property situated in New York." N.Y.C.P.L.R., s. $302(a)(4)$. 
assets. ${ }^{66}$ One possible explanation for Czechoslovakia's presence-ofassets basis for jurisdiction is that Czechoslovakia's Codes have their origins in Austrian Codes. Another possible explanation is a practical one: West Germany and Austria were, respectively, the number one and number three non-socialist importers from Czechoslovakia. ${ }^{67}$ By asserting jurisdiction on the basis of presence of assets of foreign defendants, Czechoslovakia obtains something akin to reciprocity of treatment for its nationals vis $\grave{a}$ vis nationals of these two important trading partners. Furthermore, many Western Countries, including West Germany and Austria, will not enforce a foreign judgment unless the courts of the country rendering the judgment would have had jurisdiction under the jurisdictional rules of the country where enforcement is sought. ${ }^{68}$ Czechoslovak judgments based upon presence of assets of West Germans or Austrians, in enforcement suits in West Germany or Austria, would not be subject to the defense that the Czechoslovak court rendering the judgment lacked jurisdiction under the jurisdictional rules of the country where enforcement is sought. ${ }^{69}$ Of course, West German and Austrian judgments become similarly enforceable in Czechoslovakia, assuming that all other conditions for enforcement of a foreign judgment in Czechoslovakia are met. ${ }^{70}$

Jurisdiction based on the presence of a commercial representative or agent $t^{71}$ may be interpreted as the equivalent of long-arm statutes in the U.S. which assert jurisdiction over any nondomicilary who, in person or through an agent, transacts any business within

66. Germany, Austria and Sweden use presence of assets as a basis for in personam jurisdiction according to Nadelmann, "The Uniform Law on the International Sale of Goods: A Conflict of Laws Imbroglio," 74 Yale L.J. 449, 457 n. 52 (1964). Germany, Austria, Japan and the Swiss Cantons were reported to assert in personam jurisdiction on the basis of presence of assets by Nadelmann, supra n. 65 at 331 .

67. U.S. Department of Commerce, "Basic Data on the Economy of Czechoslovakia," 30 Overseas Business Reports 15 (May, 1966). Ranking of importers from Czechoslovakia was based upon 1964 trade statistics. The current Czechoslovak Code of Civil Procedure was enacted in 1963.

In 1970 Czechoslovakia's main Western trading partners were West Germany, Britain, Austria and France, in that order. "Foreign Trade Trends: Czechoslovakia," 4 Am. Rev. East-West Trade 23 (1971).

68. See von Mehren and Trautman, "Recognition of Foreign Adjudications: a Survey and a Suggested Approach," 81 Harv. L. Rev. 1601, 1612 (1968); Baeck, "Enforcement of Judgments Obtained Under Statutes Typified by 'Long-Arm' and 'Single Act' statutes-In Austria," Am. Bar. Ass'n., Int'1 \& Comp. L. Section, Proceedings 210, 211 (1964).

69. But cf. Graupner, "Some Recent Aspects of the Recognition and Enforcement of Foreign Judgments in Western Europe," 12 Int'l \& Comp. L.Q. 367,375 n. 29 (1963) who reports a bilateral Convention on the Recognition and Enforcement of Foreign Judgments between West Germany and Austria which denies recognition or enforcement where the rendering court's jurisdiction was solely based upon presence of assets within its territory. Compare EEC Convention, infra n. 81.

70. But cf. Graupner, ibid.

71. See text accompanying $n .55$ supra. 
the state. ${ }^{72}$ It is not clear whether the Czechoslovak courts will interpret this provision to allow jurisdiction over a foreign corporation whose President is staying in a Prague hotel while awaiting negotiation of a trade agreement when the suit involves a matter unrelated to the trade agreement being negotiated. U.S. law appears to be equally unclear in this situation. ${ }^{73}$ Whether a Czechoslovak court would assert jurisdiction over General Motors, if a franchised dealer was staying in Prague negotiating a contract to sell trucks, is also unclear. ${ }^{74}$

Jurisdiction based upon the situs of "the fact establishing the right to compensation for damages"75 is similar to the provision in some U.S. long-arm statutes which confer jurisdiction on the court within whose territory damage results from a tortious act committed outside the territory. ${ }^{76}$ The main difference between the Czech-

72. See e.g. the New York long-arm statute, N.Y.C.P.L.R. s. 302 (1).

73. The issue in U.S. law would be whether there are sufficient "minimum contacts" to support jurisdiction. International Shoe Co. v. Washington, 326 U.S. 310,66 S. Ct. 154,90 L. Ed. 95 (1945). If there were sufficient "minimum contacts", the state could entertain jurisdiction over the nondomiciliary even though the cause of action was unrelated to the nondomiciliary's activities within the state. Perkins v. Benguet Consolidated Mining Co., 342 U.S. 437, 72 S. Ct. 413, 96 L. Ed. 485 (1952).

74. Compare Duple Motor Bodies, Ltd. v. Hollingsworth, 417 F.2d 231 (CA 9 1969) (long-arm statute applied to English corporation) and Delagi v. Volkswagenwerk, A.G., 4 Int'l Lawyer 406 (1970) (New York refused to apply long-arm statute to German Corporation). See also Taca International Airlines, S.A. v. Rolls-Royce of England, Ltd., 15 N.Y.2d 129, 204 N.E.2d 329 (1965). In Taca an El Salvador corporation successfully asserted jurisdiction in New York against a British corporation for damage resulting from an airplane crash in Nicaragua allegedly caused by a defective engine manufactured in England. The British corporation's contact with New York was that it owned $100 \%$ of the stock in a Canadian corporation, which owned $100 \%$ of the stock in a Delaware corporation, which was authorized to do business in New York and maintained an office in New York. The New York Court of Appeals found that the Delaware corporation was merely a department of the British corporation and not a truly independent entity. But cf. Velandra v. Regie Nationale des Usines Renault, 336 F.2d 292 (CA 6 1964).

75. See text accompanying $n .56$ supra.

76. See e.g. s. 302 of the New York long-arm statute which provides:

(a) [A] court may exercise personal jurisdiction over any non-domicilary ...., who in person or through an agent:

(2) commits a tortious act within the state. . , or

(3) commits a tortious act without the state causing injury ... within the state, .... if he

(i) regularly does or solicits business, or engages in any other persistent course of conduct, or derives substantial revenue from goods used or services rendered, in the state, or

(ii) expects or should reasonably expect the law to have consequences in the state and derives substantial revenue from interstate or international commerce.

However, it is possible for the Czechoslovak courts to read Code Civ. Proc. s. 87 (which provides that venue exists at the situs of the fact establishing the right to compensation for damages) as merely providing another proper forum in Czechoslovakia when there exists general jurisdiction over the defendant based upon some other grounds. See n. 80 infra. 
oslovak provision and the U.S. long-arm statutes is that the U.S. statutes specifically require something more than mere resulting damage in the territory of the forum state, while the Czechoslovak act does not. ${ }^{77}$

There appears to be no provision in U.S. state law comparable to s. 87(d) of the Czechoslovak Code of Civil Procedure ${ }^{78}$ which claims jurisdiction at the seat of a socialist organization "asserting rights established in the course of the performance of its tasks." This seat of the socialist organization rule has its closest counterpart in art. 14 of the French Civil Code which asserts jurisdiction over foreigners for obligations contracted by them to French persons. Both the French and the Czechoslovak rules base jurisdiction over the defendant upon the nationality of the plaintiff. The defendant may be sued in the courts of the plaintiff's state even though the defendant has never been physically present or done business in the plaintiff's state, and the transaction in question has no.substantial connection with that state. ${ }^{79}$ Like the German property basis for in personam jurisdiction, ${ }^{80}$ art. 14 of the French Civil Code has been harshly criticized because of its unfair effects on some foreign defendants. ${ }^{81}$ The analogous provision in Czechoslovak law is subject to similar criticism. Although the seat basis for Czechoslovak jurisdiction does provide equality of treatment for Czechoslovak organizations dealing with Frenchmen, it is unlikely that judgments rendered in either country would be enforceable in the other when jurisdiction is based on the nationality of the plaintiff. ${ }^{82}$

Venue (and therefore also jurisdiction) is also provided for in various laws other than the Code of Civil Procedure, e.g. it is established at the place where damage was caused by the means of transport under s. 16, law no. 63/1951/C. of L. ${ }^{83}$

77. See e.g. s. 302 (a) (3), N.Y.C.P.L.R.

78. See text accompanying $n .59$ supra.

79. Nadelmann, supra n. 65 at 321 (1961).

80. See n. 66 supra. Czechoslovak courts would interpret the seat-of-the socialist-organization rule (Code Civ. Proc. s. $87(\mathrm{~d})$ ) to be a "true" venue provision, applicable only when there exists in Czechoslovakia a court with general jurisdiction over the defendant, since s. 87 begins as follows: "Besides the court of general jurisdiction of the defendant . . . ."

81. Nadelmann, supra $n$. 65. It is not surprising that the EEC Convention on Jurisdiction and the Enforcement of Civil and Commercial Judgments of 27 Sept. 1968 states in art. 3 that persons domiciled in one contracting state cannot be sued in another contracting state on the basis of art. 23 of the German Code of Civil Procedure or art. 14 of the French Civil Code. The text of the EEC Convention can be found in 1 Common Market Law Supplement no. 1, p. 158 (1970).

82. French courts will not enforce foreign judgments where jurisdiction of the foreign court is grounded solely upon the nationality of the plaintiff. See von Mehren \& Trautman, supra n. 68 at 1613 . Czechoslovak courts require reciprocity for enforcement of foreign judgments. See text accompanying $n .103$ infra.

83. Bystricky, Základy Mezinárodního Práva Soukromého, supra n. 51 at $457(1958)$. 
In light of the extensive jurisdiction of Czechoslovak courts, it may seem surprising that Czechoslovakia also allows prorogation. However, for the purpose of recognition and enforcement of Czechoslovak judgments abroad, assertion of jurisdiction on the basis of a valid prorogation clause may be useful in that many countries will not enforce a foreign judgment unless the country rendering the judgment would have had jurisdiction under the jurisdictional rules of the country where enforcement is sought. The Private International Law Act provides that, with respect to property rights, the parties may by written agreement establish the jurisdiction of Czechoslovak courts (prorogation) but may not limit the compe-

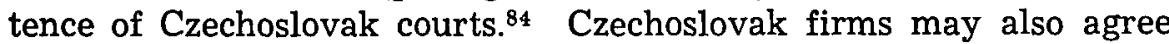
in writing on the competence of foreign courts. ${ }^{85}$ The prohibition against the limitation of the competence of Czechoslovak courts is a restriction on the power of the parties to alter the court structure, e.g. the Supreme Court can not be made the court of first instance by the parties. ${ }^{80}$ This provision does not expressly provide for nor prohibit derogation of Czechoslovak court jurisdiction, although the courts could interpret the provision as expressly allowing or disallowing derogation. A third alternative would be to interpret the provision to allow derogation if the plaintiff will not be unfairly prejudiced, as is done in the U.S. ${ }^{87}$

Some U.S. courts refuse to enforce derogation clauses if unreasonable at the time of litigation, i.e. seriously imparing plaintiff's ability to pursue his cause of action..$^{88}$ Since all Czechoslovak foreign trade is conducted by governmental monopolies subordinate to the Minister of Foreign Trade, it is arguably unnecessary for one branch of the Czechoslovak government (the judiciary) to protect another branch of the Czechoslovak government (the foreign trade ministry) from derogation clauses improvidently agreed to by the latter. Of course, if there is an unforeseen change of circumstances between the date of agreement and the commencement of litigation making the derogation clause unreasonable at the latter time, Czechoslovak courts would not be unfair, by U.S. standards, in applying a test of reasonableness to determine the effect to be given the derogation clause.

84. Private International Law Act, s. 37 (2).

85. Ibid. s. 37 (3).

86. Singer, supra n. 50 at 548 .

87. See e.g. Central Contracting Co. v. C.E. Youngdahl \& Co., Inc., $418 \mathrm{~Pa}$. 122, $209 \mathrm{A.2d} 810$ (1965). "Mere inconvenience or additional expense is not the test of unreasonableness. . ." Id. at 133, 209 A.2d at 816 . Restatement, Contracts, s. 558. Cf. art. 5, 6 of the 1966 Hague Convention on the Choice of Court. "Unless the parties have otherwise agreed only the chosen court or courts shall have jurisdiction." Art. 5.

88. Central Contracting Co. v. C.E. Youngdahl \& Co., Inc., ibid. 


\section{Jurisdiction of the Czechoslovak International Trade Arbitra- tion Commission}

The Czechoslovak International Trade Arbitration Commission (hereafter the "Arbitration Commission") is attached to the Czechoslovak Chamber of Commerce, ${ }^{89}$ and its "jurisdiction", like the jurisdiction of most arbitration commissions, depends on its selection by the parties to settle their disputes. There are, however, several limitations on the jurisdiction of the Arbitration Commission even if selected by the parties.

First, the Arbitration Commission's jurisdiction is limited to "property claims arising out of international trade".90 The subject matter jurisdiction of the Arbitration Commission is therefore "primarily" the same as the subject matter regulated by the ITC.91

Furthermore, in order to be arbitrable, claims must arise out of "matters that would otherwise be within the jurisdiction of courts. ..."92 Choice of law rules contained in the Czechoslovak Private International Law Act determine which state's jurisdictional rules are to be the standard for deciding whether the subject matter of the arbitration agreement is within the jurisdiction of the courts. $^{\text {93 }}$

Subject matter jurisdiction can also be limited by agreement of the parties in the arbitration agreement, but if not so limited, the Arbitration Commission will have jurisdiction to decide all rights arising out of or connected with the legal relations specified in the arbitration agreement, as well as the validity of the legal relations. ${ }^{94}$

Jurisdiction of the Arbitration Commission also depends on the validity of the arbitration agreement. Since the absence of an express choice of law in the arbitration agreement will result in the presumption that the parties intended the law of the seat of the arbitration body to be applicable, ${ }^{95}$ failure to specify the applicability of foreign law will usually result in the application of Czechoslovak law to determine the validity of the agreement. Under Czechoslovak law the arbitration agreement must usually be in writing to be enforce-

89. For an analysis of the organizational structure of this commission see King-Smith, "Communist Foreign Trade Arbitration," 10 Harv. Int'l L.J. 34 (1969).

90. International Arbitration Act, s. 2. See also s. 14, Rules of the Arbitration Court of the Chamber of Commerce of Czechoslovakia in Prague, in Kos-Rabcewicz-Zubkowski, East European Rules on the Valdidity of International Commercial Arbitration Agreements, Appendix 1, 135 (1970).

91. See text accompanying $n$. 48 supra.

92. International Arbitration Act, s. 2. Thus, for example, labor disputes, which under Czechoslovak law are to be settled by the organs of the Revolutionary Trade Union Movement, are not arbitrable. Zourek, supra n. 47 at 236 .

93. Zourek, ibid. at 236 .

94. International Arbitration Act, s. 3 (2).

95. Kos-Rabcewicz-Zubkowski, supra n. 90 at 84 . 
able, but it is sufficient if "the arbitration clause is contained in a written offer to conclude a sales or other contract and the other party accepts the offer not in writing but in a manner which makes its acceptance of the offer quite obvious."

If other than Czechoslovak law is to be applied to the substance of the transaction, then such other law will also determine the formal validity of the arbitration agreement, i.e. if the law of country $\mathrm{X}$ applies to a sales contract, and the law of country $\mathrm{X}$ allows oral arbitration agreements, then the oral arbitration agreement is valid. One Czechoslovak writer has argued that an arbitration agreement is also valid if it is valid under the law of the place where it was concluded.97 The view that an oral arbitration agreement is valid if valid under either lex loci contractus or lex causae is also supported by Czechoslovak case law..$^{98}$

\section{Recognition and Enforcement of Foreign Judgments and Arbitral Awards}

The recognition and enforcement of foreign judgments in Czechoslovakia is regulated by the Private International Law Act, while the recognition and enforcement of foreign arbitral awards is regulated by the International Arbitration Act. In general, both acts deny enforcement of foreign decisions if:

1) there is lack of jurisdiction,

2) there is lack of procedural due process,

3) there is lack of reciprocity, or

4) they are contrary to Czechoslovak public order.

There are, however, substantial differences between the treatment of the grounds for non-enforcement in the two Acts.

Czechoslovak courts will not enforce a foreign judgment unless the foreign court rendering the judgment would have had jurisdiction under Czechoslovak jurisdictional rules.99 Furthermore, a foreign judgment will not be enforced if Czechoslovak courts have exclusive jurisdiction over the dispute. ${ }^{100}$ The Czechoslovak Code of Civil Procedure does not specify the situations in which Czechoslovak courts have exclusive jurisdiction. Questions about the jurisdiction of an arbitral body over the parties to a dispute are unlikely

96. Zourek, supra n. 47 at 237. The principles enunciated in Matter of Doughboy Industries, Inc., 17 A.D.2d 216, 233 N.Y.S.2d 488 (1962), appear to be the same as the principles under Czechoslovak law, i.e. if the buyer orally or by conduct accepts the seller's written offer (including a provision to arbitrate disputes), then the buyer will be bound by the arbitration clause. If the buyer sends a conflicting order form (without an arbitration clause) than the parties will not be bound by the arbitration clause in the seller's written offer.

97. Zourek, supra n. 47 at 239.

98. Kos-Rabcewicz-Zubkowski, supra n. 90 at 36-40.

99. Private International Law Act, s. 64(a). See discussion accompanying notes $61-76$.

100. Private International Law Act, s. 64(a). 
to arise since an arbitration body will usually only hear a dispute if it was chosen by the parties to hear the dispute. Lack of subject matter jurisdiction of the foreign arbitral body (see text at $n .90$ supra) and validity of the arbitration agreement (see text at $n .96$ supra) are likely to be the major jurisdictional issues involved in determining the enforceability of an award issued outside of Czechoslovakia.

Lack of procedural due process includes similar deficiencies in foreign judicial or arbitral proceedings. E.g. lack of notice of the proceedings or deprivation of a party's right to argue before the arbitrators would make either a foreign judgment or foreign arbitral award unenforceable in Czechoslovakia. Also, a foreign arbitral award is not enforceable in Czechoslovakia if the award "condemns a party to a performance that was not prayed for by the entitled party." 101 However, there does not appear to be any analogous requirement that a foreign court's judgment be consistent with the remedies specifically requested in the pleadings.

Foreign arbitral awards will not be enforced if reciprocity is not guaranteed, but reciprocity is deemed guaranteed if the foreign country "declares foreign arbitration awards enforceable, subject to reciprocity of treatment.102 There is no similar provision for deeming reciprocity guaranteed with respect to the enforcement of foreign judgments. ${ }^{103}$ In all probability, judgments of U.S. courts enforcing Czechoslovak judgments would not meet the "guaranteed factual reciprocity" requirement since many European countries have interpreted reciprocity to be guaranteed only when it is provided for by statute or treaty. ${ }^{104}$ Furthermore, reciprocity is not required for the enforcement of foreign judgments if the party against whom the judgment is directed is not a Czechoslovak subject, ${ }^{105}$ but this exception to the requirement of reciprocity is not expressly applicable to the enforcement of arbitral awards. The exception to the requirement of reciprocity for the enforcement of foreign judgments when the judgment is not against a national of the enforcing state, is apparently consistent with U.S. practice. ${ }^{108}$

The most significant difference in treatment of foreign arbitral

101. International Trade Arbitration Act, $\S 20$ (b). Act no. 98/1963.

102. International Arbitration Act, s. 30.

103. Private International Law Act, s. 64(e).

104. Austria, Germany and Spain are three European countries which do not recognize reciprocity on the basis of judge-made law. Homburger, "Recognition and Enforcement of Foreign Judgments," 18 Am. J. Comp. L. 367, 370 (1970).

105. Private International Law Act, s. 64(e).

"[I]t would not be logical, for example, to insist on reciprocity, if the foreign decision benefits a Czechoslovak interprise or if it concerns only foreign subjects." Bystricky (New Czechoslovak Act), supra n. 51 at 209, 232 (1963).

106. Direction der Disconto-Gesellschaft v. United States Steel Corp., 300 F. 741 (S.D.N.Y. 1924), aff'd 267 U.S. 22, 45 S. Ct. 207, 69 L. Ed. 495 (1925). Cf. Hilton v. Guyot, 159 U.S. 113, 16 S. Ct. 139, 40 L. Ed. 95 (1895). 
awards and foreign judgments derives from the fact that Czechoslovakia is a party to several multilateral conventions dealing with foreign trade arbitration. The European Convention on International Commercial Arbitration, concluded at Geneva in 1961, has been ratified by Bulgaria, Czechoslovakia, Hungary, Poland, Rumania, the USSR, Yugoslavia, Austria and West Germany. ${ }^{107}$ Parties to the New York Convention on the Recognition and Enforcement of Foreign Arbitral Awards of $1958,{ }^{108}$ as of 1 January 1971, included Austria, Bulgaria, Czechoslovakia, Finland, France, West Germany, Greece, Hungary, India, Israel, Italy, Japan, the Netherlands, Norway, Poland, Rumania, Switzerland, the USSR (including Byelorussia and Ukraine), the United Arab Republic, the U.S. and 15 developing countries. ${ }^{109}$ The New York Convention assures recognition and enforcement, in the territory of any contracting state, of arbitration decisions rendered in the territory of any other state, ${ }^{110}$ subject to the defenses against recognition and enforcement specified in art. $\mathrm{V}$ of the Convention. ${ }^{111}$ Insistence by socialist trading firms for arbitration in their own country is likely to increase in intensity as foreign recognition and enforcement of domestic arbitral awards becomes less difficult and more certain. ${ }^{112}$

\section{Chorce of LAw}

\section{A. Party Autonomy to Choose Foreign Law}

Party autonomy to choose foreign law was limited by the 1948

107. Wilczynski, The Economics and Politics of East-West Trade 298 (1969). Membership data is based on information supplied to Mr. Wilczynski by the Secretariat of the Economic Commission for Europe in a letter dated 4/10/66. 108. TIAS 6997; 330 UNTS 3; 21 UST 2519. Czechoslovakia is also a party to the convention on the Enforcement of Foreign Arbitral Awards, Geneva, 1927; League of Nations, Treaty Series, vol. XCII, pp, 301 ff. but the 1927 Convention has no effect between parties to the 1958 Convention. New York Convention, art. VII (2).

109. Treaties in Force, Dept. of State Pub. no. 8567, p. 265 (1971). The New York Convention entered into force for the United States 29 December 1970. See Foreign Arbitral Awards Convention, Public Law 91-368; 84 Stat. 692; 9 U.S.C.A. Secs. 201 to 208.

110. The United States has declared that it will apply the Convention to the recognition and enforcement of awards made only in the territory of another Contracting State and that it will apply the Convention only to differences arising out of legal relationships, whether contractual or not, which are considered as commercial under U.S. domestic law. See Treaties in Force, ibid. Authority for the U.S. reservations is contained in art. 1(3) of the Convention.

111. Defenses include: invalidity of the arbitration agreement, incapacity of the parties, lack of proper notcie of arbitration proceedings, inability to present one's case in the arbitration proceedings, award beyond the scope of the submission to arbitration, improper arbitral procedure or composition of arbitral board, competent authority has set aside or suspended the award, subject matter of arbitration was not arbitrable in country in which enforcement is sought or enforcement of the award would be against the public policy of the country in which enforcement is sought.

112. For a general discussion of other reasons for insistence on domestic arbitration, see generally Wilczynski, supra n. 107 at 294-307. 
Czechoslovak Code of International Procedure to foreign law with a significant relation to the parties' legal relations and to the provisions of foreign law not in conflict with the imperative provisions (jus cogens) of the law which would have been applicable in the absence of a choice by the parties. ${ }^{113}$ One of the consequences of the "imperative law" restriction was that the parties could not choose the application of foreign law to regulate rights in movable and immovable property situated in Czechoslovakia because such relations were governed by imperative provisions of Czechoslovak law. ${ }^{114}$ This result was especially important to the international sale of goods since it meant that the acquisition and extinguishment of rights in movable property located in Czechoslovakia were not subject to regulation by foreign law. ${ }^{115}$

The 1963 Private International Law Act eliminated the restrictions imposed by the 1948 Act on the parties' autonomy to choose foreign law. ${ }^{116}$ Under the 1963 Act the chosen foreign law need not have a close relationship to the transaction and the imperative provisions of Czechoslovak law do not apply in derogation of the chosen foreign law. The parties may therefore choose a foreign law to govern the transfer of title in the goods. ${ }^{117}$ However, since the parties can only choose foreign law to govern their "mutual property relations", 118 the scope of ownership of the goods (mainly the right of use) is always determined by Czechoslovak law if the goods are situated in Czechoslovak territory. ${ }^{119}$

The public order exception to the application of foreign law ${ }^{\mathbf{1 2 0}}$ can also be considered as a limitation on the parties' autonomy in choosing foreign law, although the public order exception could also prevent the application of foreign law in cases where foreign law was the governing law on the basis of choice of law rules. One

113. S. 9, Law no. 41/1948 Sb. An English translation of this provision of the 1948 Law can be found at Ionesco and Nestor, "The Limits of Party Autonomy-I," in Schmitthoff, supra n. 32 at 189 . See also Szazy, Private International Law in the European Democracies 276 (1964).

114. Szazy, ibid. 227.

115. Ibid. 222.

116. Private International Law Act, s. 9.

117. Kucera, "Mobilní konflikty pri prechodu ulastnického práva podle mezinárodní kupni smlouvy (The "Conflicts Mobiles" at Transfers of Ownership in Connection with International Sales Contracts)," 12 Casopis pro Mezinárodni Právo (Journal of International Law) 39, 45-48 (1968); Private International Law Act, s. 12. Even though transfer of the risk of loss is regulated separately from the transfer of title question under the International Trade Code (and, also under the Uniform Commercial Code and the Hague Sales Act), the transfer of title question is still important because it determines when the buyer has the right to dispose of the goods. Lunz, "Conflict of Laws in International Sales: Theory and Practice of Socialist Countries," 114 Recueil des Cours 1 (1965).

118. Private International Law Act, s. 9.

119. Kalensky and Kopac, supra n. 9 at 156.

120. Private International Law Act, s. 36. 
Hungarian lawyer has concluded that "the choice of law conflicting with so-called imperative rules should also be considered one defeating public policy,"121 but the Czechoslovak public order exception is only applicable when the foreign law is "contrary to those principles of the social and governmental system of the Czechoslovak Socialist Republic and its law whose observance must be required without exception."122 (Emphasis added.) Bystricky lists as examples of such principles, the equality of races or sexes, regulations relating to children and foreign exchange regulations. ${ }^{123}$

Choice of law by the parties does not require a writing but does require proof beyond a doubt of the manifested will of the parties. ${ }^{124}$ Since businessmen engaged in international trade are usually sufficiently aware of the use of choice of law clauses in contracts, this provision arguably could be improved by requiring that the choice of law be in writing in order to be effective.

\section{B. When the Parties Do Not Choose the Governing Law}

S. 10(1) of the Private International law Act states:

If the parties do not choose the governing law, their mutual obligations shall be governed by the law whose application is in keeping with a reasonable settlement of the respective obligation.

Bystricky describes this as being parallel to the "center of gravity" test. ${ }^{125}$ S. $10(2)$ of the Private International Law Act provides specific choice of law rules for different types of contracts. These rules are deemed to be generally in keeping with a reasonable settlement in much the same manner as provided in the Restatement Second, Conflict of Laws. ${ }^{120}$ Although the specific rules in s. 10(2)

121. Madl, Foreign Trade Monopoly: Private International Law 104 n. 51 (1967).

122. Private International Law Act, s. 36. Of course, the fact that a provision of Czechoslovak law is imperative is some evidence that it embraces a principle of Czechoslovak law or social or governmental organization. However, the scope of imperative provisions probably exceeds the scope of the normal public order exception. See Schmitthoff, "The Law of International Trade: Its Growth, Formulation and Operation," in Schmitthoff, supra n. 32 at 31-32.

123. Bystricky, (New Czechoslovak Act), supra n. 51 at 228. See also Lunz, supra n. 117 at 15 where he states that, "[T] here have been no instances in Soviet practice (and I believe in the practice of other Socialist States) when this devise of public policy has been applied in cases of foreign trade transactions."

124. Private International Law Act, s. 9.

125. Bystricky (New Czechoslovak Act), supra n. 51 at 218 . Restatement 2d, Conflicts of Laws and the UCC also provide for a "center of gravity" test. See Ehrenzweig, Conflict of Laws 464 (1962).

126. Compare Restatement 2d, Conflicts of Laws, s. 191 which creates a presumption that the law with the most significant contacts is the law of the state where delivery was to be made, with the Private International Law Act, s. 10(2) which creates a presumption that the law of the state where the seller has his seat is in keeping with a reasonable settlement of the dispute. 
are said to be only suggestions which are not binding on the judge, at least one Czechoslovak scholar has concluded that the judge must give reasons why the applicable rule in that section does not provide for a reasonable settlement of the dispute, if the judge is to choose a law other than that specified.127 The Czechoslovak law arguably provides more certainty and less fairness than an unrestricted "center of gravity" or a policy oriented approach ${ }^{128}$ would provide, but the appearance of fairness (by the use of non-manipulable rules) is probably more important in East-West trade than the actual achievement of fairness.

Most of the specific rules in s. 10(2) apply the principle that the governing law is the law of the seat (domicile) of the party rendering the service or selling the goods. Since this is the same principle applied to Comecon trade under the General Conditions and is similar to the Restatement Second principles, it is difficult to argue that these provisions are intended to discriminate against trade partners from capitalist states. ${ }^{129}$

\section{Validity of the Contract}

In general, lex causae (the law governing the substance of the contract) governs, inter alia, the requirements of form, when a contract has been concluded, the power of agents to bind their principals and the effects of fraud and duress. ${ }^{130}$ There appear to be three exceptions to this principle which are important to East-West trade:

First, legal capacity of legal persons is determined by the law of their place of incorporation. ${ }^{131}$ Secondly, all requirements of form, other than the requirement of a writing, are satisfied if the requirements of form are satisfied at either lex causae or lex regit actum (the place where the will to act was expressed) ${ }^{132}$ Thirdly, other questions of validity of legal acts are determined under lex

127. Rohlik, Gvod do Mezinárodního Práva Soukromého (Basic Principles of Private International Law) 202 (1968).

128. For a discussion of the policy oriented approach see Sedler, "Babcock v. Jackson in Kentucky: Judicial Method and the Policy-centered Conflicts of Laws," $56 \mathrm{Ky}$. L.J. 27 (1967); Sedler, "Characterization, Identification of the Problem Area, and the Policy-centered Conflict of Laws: An Exercise in Judicial Method," 2 Rutgers Camden L.J. 8 (1970).

129. Art. 110, 1968 General Conditions; Art. 74, 1958 General Conditions.

130. Private International Law Act, s. 4.

131. ITC, s. 9.

132. Private International Law Act, s. 4. The ITC only requires a writing in a limited number of special circumstances, e.g. agreement to conclude a future contract (s. 119); substitution of a new agreement (s. 258); release of a written obligation (s. 263); express warranties (s. 314); clauses prohibiting re-exportation (s. 395); agreements to restrain trade (s. 398); exclusive purchase contracts (s. 410); preferential purchase contracts (s. 415); charter parties (s. 566); voyage charters (s. 371); commercial representative's contract (s. 607) ; letters of credit (s. 653) ; banking guarantees (s. 665); promise of indemnity (s. 686); public tender (s.690). 
causae "unless it is otherwise provided, or unless something else is essential to a reasonable settlement. ..."133 It is possible that Czechoslovak courts would tend to choose the law upholding the validity of the contract on the basis that the parties expected to be bound and therefore the law which upholds the contract would be applied to achieve a "reasonable settlement."134

\section{Substantive Law of Obligations}

The ITC is part of the domestic law of Czechoslovakia, but since it is applied mainly to transactions between Czechoslovak nationals and foreigners, its fairness with regard to foreigners is not safeguarded by the need to promote fairness in internal transactions. Furthermore, most aspects of Czechoslovak trade with subjects of other European socialist countries are regulated by the Comecon General conditions and not by the ITC.

Of course, fairness of the substantive law, in the sense of not discriminating against foreigners, does not guarantee that the law will be applied in a non-discriminatory manner. The best evidence of the fairness of the application of the law would be reports of decided cases, but since these are not readily available outside of Czechoslovakia, reliance has been placed upon the certainty of the law as a guarantee of its fairness in application. Since the 1964 Hague Conventions are similar in nature to the ITC, i.e. they are applicable to external but not to internal trade, and since the Hague Conventions represent an international consensus on what is a fair international trade law, frequent comparisons shall be made between the Hague Conventions and the ITC.

Because the ITC has been successfully summarized in English in several articles ${ }^{135}$ and because it contains 726 provisions covering such diverse topics as agency, banking, bailment, warehousing, insurance, charter parties and voyage charters, mortgage and suretyship, the following investigation is limited to an examination of a few topics of importance to the international sale of goods.

133. Private International Law Act, s. 4.

134. "Russia's General Principles, Poland's and Czechoslovakia's codes, the French Project, Valladao's Brazilian Draft, and even the Hague Conventions and the Second Restatement concede considerable latitude to the tendency toward validation." Ehrenzweig, Private International Law 45 (1967). The tendency of courts in the U.S. to choose the law which will uphold the validity of the contract has been noted by several prominent conflicts scholars. See Ehrenzweig, supra n. 125 at 480 (1962); Leflar, American Conflicts Law 367-70 (1970).

135. Kalensky, "The New Czechoslovak International Trade Code," $1966 \mathrm{~J}$. Bus. L. 179; Kalensky and Kopac, supra n. 9; Kotora, "The New Czechoslovak International Trade Code," 1967 Diritto negli Scambi Internazionali 191, 439 (1967). 


\section{A. Imperative Provisions}

One of the most obvious differences between the ITC and the Hague Uniform Sales Law is that the former contains imperative provisions while the latter does not. ${ }^{136}$ However, since the Hague Law is more limited in its subject matter coverage than the ITC, and since the ITC does not "ostensibly" contain imperative provisions applicable to the subject matter of the Hague Law, there is no difference between the two. ${ }^{137}$ Furthermore, although the scope of applicability of the ITC is an imperative provision, the parties by agreement can often make the laws of another country applicable, thereby excluding application of the ITC.

\section{B. Commercial Usage}

It may be presumed that the parties' choice of the use of particular terms, e.g. F.O.B., C.I.F., or of the use of particular contract forms, e.g. London Cotton Association Sales Contract, Czechoslovakia's General Import Purchase Conditions, ${ }^{138}$ reflects their intent that these terms and forms be interpreted consistently with commercial practice. Therefore it is not surprising that the ITC and the Hague Uniform Sales Law refer to commercial practice in order to interpret such terms or forms. ${ }^{139}$ However, it is also possible for a court to make reference to commercial usage in interpreting a contract, even in the absence of such implied agreement of the parties. The following discussion will involve reference to commercial usage that is not expressly provided for in the contract and is not based upon the use by the parties of standard form contracts or terms commonly used in commercial practice.

While the ITC generally does not give preference to the application of commercial usage over the provisions of the Code, the Hague Uniform Sales Law does. ${ }^{140}$ This difference in the deference paid

136. ITC s. 722 lists imperative provisions and provides that other provisions are imperative "to the extent to which their mandatory nature is expressly provided for therein." The Hague Uniform Sales Law art. 3 states: "The parties to a contract of sale shall be free to exclude the application thereto of the present law either entirely or partially."

137. The following topics are included in the imperative provisions listed in s. 722: scope of the act, legal capacity of parties, validity and consequences of invalidity of legal acts, questions of representation and agency, prescription, mortgages and sub-mortgages. See Ettinger, "The Czechoslovak Law on International Transactions," 4 Int'l Law. 80, 83 (1969). No attempt was made to determine which provisions of the ITC not listed in s. 722 are imperative.

138. Czechoslovakia's General Import Purchase Conditions may be found in Business International, Developing the Eastern European Market, Appendix D (1966). Foreign contracting parties should be aware of the fact that ITC s. 116 provides for the binding of conditions "known to both parties and presented by the offeror." Compare UCC 2-207.

139. ITC, s. 116-17; Hague Uniform Sales Law, s. 9. There are some possible differences between these sections in their operation and effects.

140. Hague Uniform Sales Law, s. 9(2); ITC, s. 118. Commercial usage 
to usage is partly explainable by the different purposes and coverages of the two laws. ${ }^{141}$ The Hague Law is an attempt at reconciliation of conflicting national laws on an international level, and the most appropriate resolution of this conflict is a resolution which makes the law conform to usage rather than vice versa. However, international trade usage is still growing and it would be unwise to codify all such usages at this time. Furthermore, the Hague Law does not regulate in detail the myriad problems which can arise in international trade, and it is necessary to look beyond that Law for the law to govern the questions it leaves unanswered. ${ }^{142}$ The ITC is much more complete and detailed than the Hague Law, thereby minimizing the need to fill in its provisions by trade usage. Also, the purpose of the ITC is not to resolve conflicts between national trade laws, and therefore there is no necessity to defer to trade usage as the preferred solution.

Of course, the ITC could have deferred to trade usage on the theory that such usage most nearly reflects the expectations of the parties and the interests of international trade. But the preference of trade usage over the law was considered inadvisable in Czechoslovakia because of the legal insecurity caused by the vagueness of trade usages and the lack of expertise of many judges on the subject of trade usages and the needs of international commerce. ${ }^{143}$ Such legal insecurity could be especially harmful to East-West trade.

Because of the need for legal security in international trade, it is arguable that the Czechoslovak solution to the problem of trade usage would be preferable to the Hague Uniform Sales Law solution even in a uniform international sales law. A uniform law should be designed to fit the needs of international commerce, but when it fails to accomplish this goal, the inconvenience to the parties who would have to draft contractual provisions to escape application of express provisions of the uniform law may be less than the inconvenience caused by uncertainty of trade usages. ${ }^{144}$ Exceptions to this general rule could be created to give preference to international

in the ITC encompasses only international commercial usage in particular trades whereas commercial usages in the Hague Sales Act may encompass general, local and regional commercial usages. 1 Diplomatic Conference, supra n. 35 at 34-35. However, under the Hague Uniform Sales Law, "A court . . retains the power to set aside, as contrary to the public policy of its country, a usage which appears to it to disregard a fundamental right of one of the parties." Commentary by Tunc, ibid. at 363 .

141. Berman, "The Uniform Law on International Sale of Goods: A constructive Critique," 30 Law and Contemp. Prob. 354, 368 (1965).

142. See generally Berman, ibid., who concludes that national law should be made available as a source of law for questions unanswered by the contract, trade usage or the provisions of the Hague Sales Law.

143. Kalensky and Kopac, supra n. 9 at 169 . For a discussion of other problems involved in applying trade usages see 1 Diplomatic Conference, supra n. 35 at 34 .

144. Compare Berman, supra n. 142. 
trade usage (as is done in the ITC) for certain types of transactions which are difficult to regulate by a uniform law, e.g. voyage charters and banking transactions.

\section{Impossibility of Performance}

Impossibility of performance existing at the time of the formation of the contract must be distinguished from subsequently arising impossibility because initial impossibility involves the validity of legal acts (jus cogens in the ITC), whereas subsequent impossibility involves the extinction of existing obligations (jus dispositivum in the ITC). The Hague Uniform Sales Law only regulates subsequent impossibility.

The ITC proceeds from the principle of objective liability, viz. parties are liable for damages caused by their failure to fulfill their obligations regardless of their culpability. ${ }^{145}$ This principle of objective liability is evident in the treatment in the ITC of initial impossibility, viz. a party to a contract who has undertaken obligations which cannot be performed is liable for the damages sustained by the other party who relied on the validity of the contract. ${ }^{146}$ Liability for damages exists even though the contract is void. ${ }^{147}$ Thus the principle of objective liability can be used to explain the separation of the issue of liability for damages from the issue of the validity of the contract.

The ITC carries over into the regulation of subsequent impossibility the principle of objective liability and separates the issues of liability for damages from the duty of performance of contractual obligations. $^{148}$ Subsequent impossibility of performance or frustration of the purpose of a contract extinguishes the obligations of performance but does not necessarily extinguish liability for damages. Only certain circumstances described in the Code (vis major) extinguish liability for damages, ${ }^{149}$ but such extinguishment does not necessarily end the duty of the parties to perform their contractual obligations. To illustrate the operation of these provisions, Bystricky gives two examples. ${ }^{150}$ In the first, the 1956 closing of the

145. Bystricky, supra n. 20 at 307; Kalensky and Kopac, supra n. 9 at 173. The law of continental Europe is also based on culpability. Soviet law is based on a rebuttable presumption of culpability. Bystricky, ibid.

146. Bystricky, ibid. at 291. Cf. Kalensky and Kopac, ibid. at 173-74. ITC s. 37 provides that "Whoever causes the nullity of a legal act, shall be liable to compensate the person to whom the said act was addressed and who suffered damage trusting its validity." This provision is interpreted as creating an obligation on the parties not to assume contractual duties which they cannot perform. Bystricky, ibid.

147. "A legal act shall be void ... if its subject is a performance which is impossible." ITC, s. 28.

148. Bystricky, supra n. 20 at 292.

149. ITC, s. 252.

150. Bystricky, supra n. 20. 
Suez Canal does not relieve the carrier of his duty to deliver the goods, but does relieve him of the liability for damages for delay caused by the necessity of circumnavigating South Africa. In the second, the failure of a seller to obtain an export license relieves the seller of his obligation to perform, but does not relieve him of liability for damages caused by his non-performance.

Under Czechoslovak law the obligation to perform is extinguished if there is factual impossibility, e.g. destruction of a specified item which was to be the subject of performance, or legal impossibility, e.g. inability to procure an import, export or foreign exchange license. Economic impossibility extinguishes the obligation to perform only if a basic change in circumstances frustrates the expressly stated basic purpose of the contract; changes in the financial standing of the debtor or the economic situation in his home country or in conditions existing in international trade do not constitute such a change in circumstances. ${ }^{151}$

Circumstances excluding liability for damages (vis major) must be of an extraordinary nature, e.g. war, disruptions in transport, natural disasters. ${ }^{152}$ Such circumstances must prevent performance and not merely make performance more burdensome. Foreseeability of the changed circumstances is only relevant in determining whether the bound party could have prevented or avoided the extraordinary circumstances. Thus it would not be relevant whether the debtor could have foreseen a war or the possibility of a tornado if he could not have prevented or avoided these occurrences.

S. 252 of the ITC states that a failure to obtain necessary licenses does not relieve a party of his liability for damages for nonperformance. Since Czechoslovakia does not require import or export licenses, ${ }^{153}$ no burden is put on Czechoslovak state trading firms by making parties liable for damages when they fail to procure a necessary license. On the other hand, many Western countries do have licensing systems, so that a substantial burden is being imposed on Western trading partners. ${ }^{154}$ Western businessmen may also be accustomed to dealing on the basis of a rule like that contained in the U.C.C. which provides that the failure of the seller to obtain an export license due to an unexpected (on the part of the seller) alteration by the government in its licensing practice, ends

151. ITC, s. 275.

152. Ibid., s. 252. Singer, supra n. 50 at 170.

153. Singer, ibid. at 174 . The state monopoly of foreign trade makes such licensing unnecessary. But see $\mathbf{n}$. 32 supra.

154. "Although the Department of Commerce provides all pertinent information concerning the broad meaning of trade regulations, the exporter must often operate blindly, in that specific contracts must be negotiated before an official decision on their licensing can be obtained. This is particularly onerous if the strategic classification of the export is questionable." U.S. Sen., 89th Cong., 1st Sess., Committee on Foreign Relations, Background Study on East-West Trade 53 (April, 1965). 
the seller's liability. ${ }^{155}$ The U.C.C. provision is reasonable for trade between capitalist countries because it is not likely that a capitalist country would refuse an export license to free its subjects from economically unprofitable deals. Yet the refusal of a license by a Socialist State may be motivated by a desire to protect its subsidiary agencies from deals which become unprofitable after they are concluded. ${ }^{150}$ Since it is not easy to determine the motivation of a state in granting or refusing to grant import and export licenses in specific cases, the ITC provides a reasonable resolution of the conflicting interests: Any state can refuse licenses on any grounds it desires, but the companies operating in that state are not excused from liability for their failure to secure a necessary license.

\section{Damages}

Like the Hague Uniform Sales Law, the ITC differentiates between minor and substantial breaches of contract.157 Both laws allow a party to terminate the contract only for substantial breaches. Differentiation between substantial and minor breaches does add to the court's power to discriminate against a party since it is impossible precisely to define this difference in a law; however, such differentiation is necessary to avoid allowing rescission when only one of ten thousand widgets does not conform to contract specifications, or for immaterial delays in delivery. The Comecon General Condi-

155. UCC 2-615.

156. In Jordan Investment Ltd. $v$. V/O Soiuznefteksport (1958), the Israeli buyer argued that the denial of an export license to the Soviet seller by the Soviet Minister of Foreign Trade did not constitute a defense to the seller's non-performance "because both the combine and the Ministry were organs of one and the same state." Domke, "The Israeli-Soviet Oil Arbitration," $53 \mathrm{Am}$. J. Int'l $L$. 787, 796 (1959). The Israeli buyer apparently did not emphasize the subsequent unprofitability of the transaction, presumably because it was obvious in that case that the reason for the Soviet denial of the export license was political, i.e. the 1956 Middle-East crisis. The Soviet Arbitral Tribunal excused the Soviet seller's non-performance on the grounds of subsequently arising impossibility of performance.

157. Hague Uniform Sales Law, art. 26-37; ITC, s. 235-38. Compare UCC $2-711,2-601,2-612$. Under the UCC a buyer is not required to accept a delivery of goods (other than a non-conforming installment delivery) which fails to conform to the contract in any respect (UCC 2-601). However, if the buyer'rejects because of a minor defect, the seller is given a reasonable time to substitute a conforming tender (UCC 2-508(2)). A buyer may reject a non-conforming installment delivery only if the non-conformity substantially impairs the value of that installment (UCC 2-612). If the non-conformity of one or more installment deliveries substantially impairs the value of the whole contract, there is a breach of the whole contract (UCC 2-612). The buyer has the right to rescind the contract whenever he rightfully rejects acceptance of a delivery of goods and the seller does not substitute a conforming tender except that in order to rescind a contract calling for delivery in installments, there must be a breach of the whole contract. See generally Hawkland, "Sales and Bulk Sales," ALI-ABA Committee on Continuing Legal Education (1958). 
tions also make the distinction between substantial and minor breaches. ${ }^{158}$

The ITC provides that only damages that are foreseeable, direct and normal consequences of the breach of contract are compensable. ${ }^{159}$ There is no consensus in Czechoslovak law concerning the concept of directness of damages. ${ }^{160}$ E.g. Kalensky and Kopac, who were active in drafting the ITC, state:

"The principle that indirect damage is not compensated indicates that the debtor is not bound to compensate damage caused to the creditor only as a result of the fact that he himself is bound to pay to a third person (e.g. the buyer to his own customer) a higher compensation, provided for by a different legal regulation (e.g. where a high contractural penalty has been fixed), than the debtor would have to pay if damage had been caused directly to the creditor." 161

However, with apparent disregard for this view of "indirectness" the Czechoslovak Arbitration Commission, in Cs. PZO K v. Turkish Firm N., ${ }^{102}$ held Turkish Firm $\mathrm{N}$ liable for damages resulting from the fact that Czech foreign trade firm $\mathrm{K}$ was obliged to pay a penalty to its Czech customer when the goods ordered in the contract between $\mathrm{K}$ and $\mathrm{N}$ were not delivered.

The note appended to the decision of the Arbitration Commission adds further complexities. It supports the arbitrators' decision that the penalty paid by the plaintiuff-buyer constitutes damages within the meaning of s. 254 of the ITC since those amounts, representing actual, direct damages, are generally recognized as such and are therefore foreseeable. However, the note criticizes basing the penalty on the domestic wholesale price, since this may vary a great deal from the purchase price and could not be foreseen at the time the contract was concluded. The use of Czechoslovak wholesale prices in calculating the lost profits which the foreign defaulting party must pay ${ }^{163}$ may result in an unexpectedly high damage liability for foreign parties in breach of contract. Because prices serve a different function in the Czechoslovak internal economy

158. "Minor deficiencies for which the seller bears liability, if their elimination cannot be postponed and does not require the seller's participation, shall be repaired by the buyer, charging the seller for the normal actual expenses." 1968 General Conditions, s. 81(2), Hoya \& Quigley trans. Delays in delivery must exceed four or six months to entitle the buyer to rescind. See 1968 General Conditions, s. 85 (1).

159. ITC, s. 254 (2).

160. Bystricky list six different meanings attached to this concept. Bystricky, supra n. 20 at $318-19$.

161. Kalensky and Kopac, supra n. 9 at 175.

162. See 11 Casopis pro Mezinárodní Právo (Journal of International Law) 60 (1967) for a report of the case, decided under the ITC.

163. ITC s. 254(1) provides for compensation of actual losses and lost profits. 
than they do in international trade, ${ }^{16,4}$ it would appear to have been fairer if the ITC measured lost profits by the average prices in the world market and limited liability in the penalty situation to a fixed percentage of the price in the foreign trade contract.

Another problem in ascertaining damages, resulting from the foreign trade practices of a socialist state, was brought to light in Cs. PZO v. Danish firm A. ${ }^{105}$ In this case, Danish firm A violated its contract to deliver a large number of cattle to the Czechoslovak buyer. The Czechoslovak firm made a substitute purchase in England even though the cattle could have been bought at a cheaper price in Denmark. Presumably the reason for making the purchase in England was to satisfy a long-term trade agreement between England and Czechoslovakia. The Czechoslovak Commercial Arbitration Commission limited the recovery by the Czechoslovak buyer to the amount by which a substitute purchase in Denmark would have exceeded the original contract price with firm A. This issue was correctly decided on the basis of the duty of the innocent party to minimize damages, but illustrates the possibility of the influence of commercial-political motives in the trading practices of socialist foreign trade firms.

\section{Conclusions}

Czechoslovak legislation has separated the bulk of the law governing foreign trade from other Czechoslovak laws, thereby facilitating the ascertainment of Czechoslovak foreign trade law and assuring foreign businessmen that their international business transactions will not be governed by the peculiarities of laws regulating relations between members of a socialist, planned economy. Some problems may arise from the division of the regulation of economic transactions into three separate laws, but these problems should not arise frequently. In general, the separate treatment of foreign trade law should add certainty to the regulation of international business transactions and make the choice of the application of Czechoslovak law to such transactions (a usual objective of state foreign trade firms) more attractive to foreign trading partners.

The Czechoslovak laws relevant to foreign trade are similar to the laws applied to such transactions by Western countries: Czechoslovak choice of law rules are similar to Restatement Second rules and many of the ITC provisions resemble provisions in the U.C.C. Although jurisdiction of Czechoslovak courts is excessive by U.S. standards, it is comparable to jurisdiction asserted in many Western European countries. This similarity of foreign trade laws may be

164. Bystricky, supra n. 20 at 314 .

165. A report of the case is at 11 Casopis pro Mezinárodni Právo (Journal of International Law) 58 (1967). 
partly the result of historical factors: Czechoslovak law traces its origins to the Austrian Code of 1811. However, a significant influence on the Czechoslovak foreign trade laws has probably been exerted by the importance of foreign trade to Czechoslovakia and the resulting necessity of making that law acceptable to foreign trading partners.

The distinguishing characteristics of Czechoslovak foreign trade law are not in what that law provides, but rather, distinguishing characteristics appear in the application of the provisions of Czechoslovak law within the framework of the Czechoslovak economic system. Changes in the economic system following the 1968 Warsaw Pact occupation have changed the significance of some Czechoslovak foreign trade laws. For example, lost profits damages have gained special significance since the post-occupation return to a directive determined pricing system. Also, the weight of the burden of liability on Czech firms for a failure to obtain an export or import license is affected by the the operation of the state monopoly of foreign trade and the extent to which enterprises other than foreign trade organizations are allowed to engage in foreign trade transactions. ${ }^{108}$ However, the Warsaw Pact occupation and the resulting movement away from enterprise profitability as the prime factor in evaluating enterprise performance is not likely to have significant effects upon the legal relationships between Czechoslovak and Western trading partners. Resurgence of the prominence of political and planning factors for Czechoslovakia's foreign trade, however, will have profound effects upon the content and direction of Czechoslovakia's foreign trade.

166. See text accompanying $n .153$ supra. 